\title{
Genetic Diversity and Low Reproductive Success in Isolated Populations of Utah Juniper (Juniperus Osteosperma, Cupressaceae)
}

Loreen Allphin

Val J. Anderson

val_anderson@byu.edu

Amy F. Hunt

Follow this and additional works at: https://scholarsarchive.byu.edu/facpub

Part of the Animal Sciences Commons, and the Plant Sciences Commons

\section{Original Publication Citation}

L. Allphin, A.F. Hunt and V.J. Anderson. "Genetic diversity and low reproductive success in isolated populations of Utah juniper (Juniperous osteosperma, Cupressaceae)." Western North American Natrualist. 67.3 (27): 323-337.

\section{BYU ScholarsArchive Citation}

Allphin, Loreen; Anderson, Val J.; and Hunt, Amy F., "Genetic Diversity and Low Reproductive Success in Isolated Populations of Utah Juniper (Juniperus Osteosperma, Cupressaceae)" (2007). Faculty Publications. 950.

https://scholarsarchive.byu.edu/facpub/950

This Peer-Reviewed Article is brought to you for free and open access by BYU ScholarsArchive. It has been accepted for inclusion in Faculty Publications by an authorized administrator of BYU ScholarsArchive. For more information, please contact ellen_amatangelo@byu.edu. 
Western North American Naturalist 67(3), ㄷ 2007, pp. 323-337

\title{
GENETIC DIVERSITY AND LOW REPRODUCTIVE SUCCESS IN ISOLATED POPULATIONS OF UTAH JUNIPER (JUNIPERUS OSTEOSPERMA, CUPRESSACEAE)
}

\author{
Loreen Allphin ${ }^{1,2}$, Amy F. Hunt ${ }^{1}$, and Val J. Anderson ${ }^{1}$
}

\begin{abstract}
Utah juniper (Juniperus osteosperma) has greatly expanded its historical range in the western United States. Management plans for the species have focused on curtailing its encroachment into sagebrush and grassland communities. These plans often include burning or other methods of elimination. These methods may result in subdivision or fragmentation of existing juniper stands. We initiated a study at Dugway Proving Ground, a U.S. Army facility, to examine the effects of fragmentation on the reproductive success of Utah juniper in isolated populations. We used enzyme electrophoresis to quantify genetic variability in isolated populations. We also determined population reproductive success by examining juniper fruits for evidence of seed abortion and/or presence of insect parasites. We compared reproductive and genetic variability in isolated populations at Dugway to 2 nonisolated and encroaching Utah juniper populations. The Dugway populations exhibited reduced seed set due to high seed abortion and/or insect seed parasitism, and a loss of genetic variability in comparison to the nonisolated populations. Additionally, there was a significant correlation between reproductive success and genetic variability.
\end{abstract}

Key words: genetic variability, inbreeding, Juniperus osteosperma, reproductive isolation, seed abortion, seed set, Utah juniper.

Utah juniper (Juniperus osteosperma) is a long-lived, shrubby tree species that is a native endemic of the western United States (Loehle 1988). Utah juniper currently covers an estimated $71,500 \mathrm{~km}^{2}$ in the west central Rocky Mountains and the Great Basin of the western United States (Terry et al. 2000b; Fig. 1). This hardy species can withstand severe drought, extreme temperatures, and rocky soil (Springfield 1976, Zarn 1977).

Utah juniper has expanded its historical geographic range in the western U.S. since European colonization (Betancourt 1987, Loehle 1988, Tausch 1999). Moreover, stands that were once open-canopied (i.e., savannalike) have become dense, thick forests (Tausch 1999). Utah juniper has also encroached into other ecological communities (i.e., sagebrush and grassland communities; Aro 1971, Tausch 1999). Ecological expansion and encroachment by Utah juniper has occurred in response to overgrazing (including the reduction of fine fuels by livestock grazing), fire suppression, and change to warmer, drier climates (Clary et al. 1974, Betancourt 1987, Tausch 1999).

Thus, much research on Utah juniper is aimed at controlling its encroachment (Aro
1971, Springfield 1976, Everett and Clary 1985, Evans 1988, Stevens 1999). Methods such as herbicide application, chaining, and controlled burning have been used to eradicate encroaching Utah juniper populations (Blackburn and Tueller 1970, Aro 1971, Bunting et al. 1987, Despain 1987). These methods often result in subdivision or fragmentation of juniper stands. The effect of this fragmentation on the integrity of remaining juniper populations has been given little consideration. Although the species is thought to be invasive, one might expect longterm genetic and reproductive consequences to result from subdivision or fragmentation of juniper populations, which is accomplished through controlled burns (Wilcox 1980, Barrett and Kohn 1991, Sun 1996, Fahrig 1997, Gaines et al. 1997, Allphin and Windham 2002).

Populations of Utah juniper that were historically isolated by elevation and distance have also become further isolated as a result of recent wildfires, which burn through existing populations by using invasive Bromus tectorum (cheatgrass) as fuel (Aro 1971, Everett and Clary 1985). If wildfires or controlled burns create even further fragmentation and reproductive isolation of juniper populations,

${ }^{1}$ Department of Plant and Wildlife Sciences, Brigham Young University, Provo, UT 84602.

${ }^{2}$ E-mail: loreen_woolstenhulme@byu.edu 


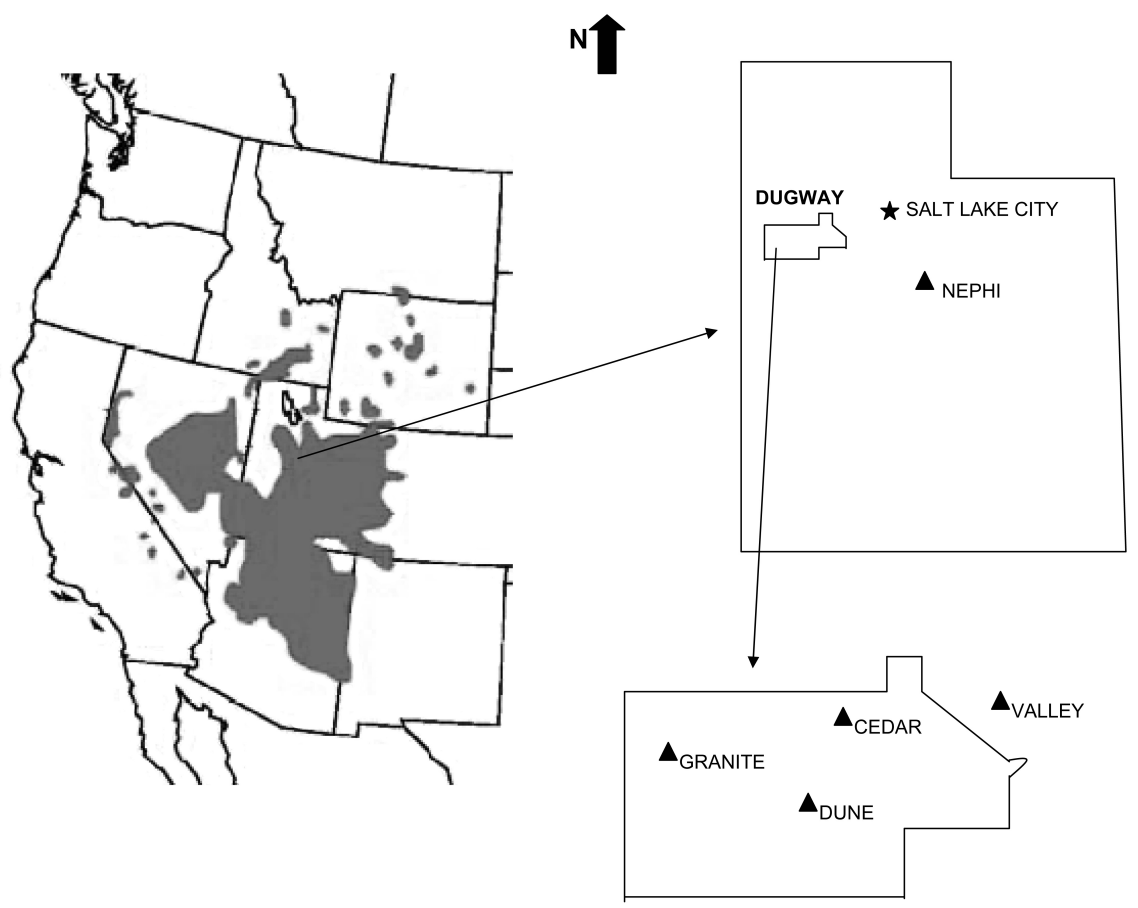

Fig. 1. Distribution of Juniperus osteosperma in Western North America, including a map of Utah indicating the 5 collection sites of J. osteosperma used in this study.

fewer nonrelated individuals may be available for mating (Levin 1984, Daehler 1999, Sorenson 1999) and inbreeding might become an increasing problem in these forest stands (Charlesworth and Charlesworth 1987, Waser 1993, Allphin et al. 2002). In isolated populations where inbreeding may ultimately result in loss of genetic diversity, reproductive success may decrease (Danzmann et al. 1986, Ledig 1986, Levin 1989, Nickrent and Wiens 1989, Daehler 1999, Sorenson 1999).

Decreased reproductive success in inbred populations may manifest itself as low seed set. Because outcrossing populations (like monoecious, wind-pollinated Utah juniper) are able to maintain potentially lethal recessive alleles in the heterozygous state (genetic load), inbreeding in isolated and/or fragmented populations may increase the frequency of homozygous combinations of lethal recessives. Populations with high levels of deleterious recessive alleles may exhibit reduced reproductive success when lethal alleles are exposed during sexual recombination, resulting in the abortion of developing seeds (Hardon 1961, Sorenson 1969, Wiens 1984, Wiens et al. 1987, Allphin et al. 2002). Moreover, genetic drift in small, isolated populations could also lead to a fixation of mildly deleterious alleles that might also limit reproductive success.

Utah juniper populations persist after fires because of the survival of a few tall (and usually very old) trees that reseed the area (Covington and Debano 1990). Population persistence in Utah juniper after fire may also be due to recruitment from an existing seed bank in the soil. Therefore, if Utah juniper populations have diminished reproductive capacity, their persistence after future fires becomes even less probable.

Isolated populations of Utah juniper at Dugway Proving Ground (DPG), a U.S. Army testing and training facility in the West Desert of Utah (est. 1942), appear to suffer from low recruitment and low population reproductive success. Initial field surveys of Utah juniper populations at DPG in spring 2000 revealed that there were fewer juveniles in the DPG populations than in nearby nonisolated juniper populations. We counted only 2 juveniles in a $3-\mathrm{km}^{2}$ area of a Utah juniper population located on Granite Mountain at DPG. In contrast, a 
Utah juniper population located $225 \mathrm{~km}$ (air distance) southeast of DPG had more than 20 juveniles in a similarly sized area. Initial examination of mature fruits of Utah juniper at DPG populations revealed high levels of seed abortion and insect parasitism of seeds.

Historically, Utah juniper populations at DPG have been geographically isolated from other populations. Fires, caused by spent ammunition during army training, have resulted in the significant loss of the already isolated Utah juniper populations at DPG. Recently, natural wildfires have also threatened, destroyed, and/or further isolated many of the juniper woodlands at DPG.

Therefore, we suggest that loss of genetic variability and reproductive isolation might be contributing to decreased reproductive success (low recruitment and low reproductive success) in isolated juniper populations at DPG. To examine the effects of fragmentation and isolation on reproductive success in Utah juniper at DPG, we assessed both reproductive success (seed set) and genetic diversity in isolated populations of Utah juniper at DPG. We examined the contribution of seed abortion and insect parasitism of seed to overall reproductive success in this taxon. We compared reproductive success and genetic diversity in these isolated populations at DPG with 2 nonisolated, expanding populations of the same species. We predicted that isolated populations of Utah juniper at DPG would exhibit lower genetic variability and lower reproductive success than nonisolated, expanding populations. We further predicted that small populations with reduced genetic diversity would also exhibit increased abortion of developing seeds because of familial breeding (inbreeding) and increased insect parasitism of seed because of decreased resistance.

\section{Methods}

\section{Study Area}

We selected 5 study populations in Utah in which to examine the effects of fragmentation and isolation on reproductive success in Utah juniper at DPG (Fig. 1). Three of the study populations were located on DPG (Granite Mountain, Cedar Mountain, and Dune; Fig. 1). The Granite Mountain (Granite) population is thought to have been isolated from the other
Dugway populations for the last several hundred years by elevation and/or distance. The Cedar Mountain (Cedar) and Dune populations have been more recently isolated by wildfire.

For comparative purposes, we also sampled 2 populations not located on DPG (Fig. 1). These control populations were large, continuous, encroaching populations growing in similar soil and climatic conditions at roughly the same elevation as the DPG populations. One population (Valley) was located in a valley $\sim 16 \mathrm{~km}$ east of DPG. The other control population (Nephi) was located at the north end of Juab County, $225 \mathrm{~km}$ south of DPG, near the town of Nephi, Utah. Both control populations were considered isolated from DPG (because of geographic distance and/or the south-southwest prevailing wind patterns) and were not thought to interbreed with the populations at DPG, either historically or currently.

\section{Field Sampling}

We collected leaf tissue and berries for genetic and reproductive studies from Utah juniper trees at all 5 of the study populations (Fig. 1). At each population, we used the pointquarter method (Cottom and Curtis 1956) to randomly select $\sim 40$ individuals from which leaf tissue and mature fruits were collected (Table 1). All leaf tissue and fruit samples were collected during the fruiting season (MarchApril) of 2000 and 2001.

Because the sampled trees were located in rough mountain terrain, as well as within areas that were near restricted weapons-testing sites at DPG, we collected samples where access roads to populations were available. Five access roads were designated for each population. From these access roads, we established 2 sampling points at 50-m distances in opposite compass directions and perpendicular to the access road. These became the sampling points for the point-quarter method (Cottom and Curtis 1956).

At each sampling point, we measured the distance from the point to the nearest tree in each of 4 quarters and the distance from the sampled tree to its nearest neighbor within each quarter. We assigned each sampled tree and its nearest neighbor to 1 of 3 age classes: seedling, juvenile (prereproductive), or mature (Bunderson 1983). From these data we determined the proportion of measured individuals 
TABLE 1. Characteristics of the 5 Utah juniper populations in this study, including population location, estimated population size, number of individuals sampled, proportions of individuals sampled and nearest neighbors in 3 age classes, and population density.

\begin{tabular}{lccccccc}
\hline Population & $\begin{array}{c}\text { Population } \\
\text { location }\end{array}$ & $\begin{array}{c}\text { Estimated } \\
\text { population } \\
\text { size }\end{array}$ & $\begin{array}{c}\text { Total } \\
\text { individuals } \\
\text { sampled }\end{array}$ & $\begin{array}{c}\text { Proportion } \\
\text { seedlings }\end{array}$ & $\begin{array}{c}\text { Proportion } \\
\text { juveniles }\end{array}$ & $\begin{array}{c}\text { Proportion } \\
\text { adults }\end{array}$ & $\begin{array}{c}\text { Populion } \\
\text { density } \\
\left(\text { individuals } \cdot \mathrm{km}^{-2}\right)\end{array}$ \\
\hline Granite & DPG & $250-300$ & 40 & 0.056 & 0.097 & 0.847 & 4.8 \\
Cedar & DPG & $300-350$ & 40 & 0.058 & 0.115 & 0.827 & 9.9 \\
Dune & DPG & 100 & 40 & 0.035 & 0.089 & 0.893 & 6.4 \\
Valley & $20 \mathrm{~km}$ east of DPG & $1000+$ & $32^{\mathrm{c}}$ & 0.194 & 0.083 & 0.722 & 28.4 \\
Nephi & $250 \mathrm{~km} \mathrm{SE} \mathrm{of} \mathrm{DPG}$ & $1000+$ & 40 & 0.194 & 0.082 & 0.726 & 9.5 \\
\hline
\end{tabular}

aJuveniles are prereproductive individuals, not the current year's seedlings.

bDugway Proving Ground, U.S. Army testing facility in the West Desert of Utah.

cOnly 32 individuals were sampled due to problems associated with access to private property.

falling into each age class for each population.

We used the point-to-organism and nearest-neighbor distances to compute an unbiased estimate of juniper density (Diggle 1975). Diggle's (1975) estimate of density is a compound estimate based on the geometric mean of juniper density computed from point-quarter data (point-to-organism distances) following Pollard (1971) and the density computed from nearest neighbor distances following Byth and Ripley (1980).

\section{Reproductive Analyses}

For reproductive analyses, we randomly collected approximately 40-60 juniper berries from all parts of each mature tree that we sampled, and then we stored the berries in a cool, dry place until analysis. For reproductive analysis, these sampled berries were split open and the seeds were identified as normal, aborted, or parasitized by larval insects.

From these reproductive data, we calculated mean seed-per-ovule $(\mathrm{S} / \mathrm{O})$ ratio (i.e., the proportion of ovules that mature into seeds), mean proportion seed aborted, and mean proportion seed parasitism by insect larvae for each population. (We note here that $\mathrm{S} / \mathrm{O}$ ratios are likely to be overestimates because we do not take into consideration berries that might have fallen from the trees because of the abortions of premature seeds.) An arcsine transformation was performed to normalize proportion data for statistical analyses (Zar 1996). Significant differences in population and yearly effects of these parameters, as well as year-population interactions, were identified using a 2-way ANOVA. We ran post hoc Tukey comparisons to assess significant differences among the individual populations for these means. All sta- tistical analyses were performed using SYSTAT 9 (SPSS 1999).

We looked for a potential relationship between stand density and reproductive success. In order to determine if these 2 parameters were correlated, we used SYSTAT 9 to perform 3 linear regressions (using mean population values across both years of study, $n=5$ ): stand density against $\mathrm{S} / \mathrm{O}$ ratio, stand density against insect seed parasitism, and stand density against seed abortion.

\section{Allozyme Analyses}

We determined genetic variability within and among the sampled populations using enzyme electrophoresis. Leaf tissue samples collected from field populations were placed in moistened plastic bags and stored on ice (or in a refrigerator) until they could be ground for electrophoresis (<48 hours). Tissue samples were ground in a PVP-phosphate grinding buffer (Soltis et al. 1983). The ground material was absorbed into Whatman $3 \mathrm{MM}$ filter paper wicks and stored at $-70^{\circ} \mathrm{C}$ until electrophoresis. Each tissue sample was surveyed for genetic variability at 15 enzyme loci using a variety of gel and electrode conditions (Soltis et al. 1983, Odrzykoski and Gottlieb 1984). Twelve enzyme loci provided consistent, variable, and interpretable results (Table 2).

Diversity statistics were calculated for the 12 variable loci following Wright (1943), Weir (1996), and Hartl and Clark (1997). Genetic data analysis (GDA) software was used to analyze allelic data (Lewis and Zaykin 2001). The following descriptive statistics were computed to assess the genetic diversity within each population: mean observed heterozygosity $\left(\mathrm{H}_{\mathrm{O}}\right.$; direct estimate), Hardy-Weinberg (H-W) 
TABLE 2. Enzymes and buffer systems used in allozyme population genetic analysis of Juniperus osteosperma.

\begin{tabular}{lcccc}
\hline Enzyme & Acronymn & EC number & Buffers $^{\mathrm{b}}$ & Loci scored $^{\mathrm{b}}$ \\
\hline Aldolase & Ald & 4.1 .2 .13 & $11, \mathrm{M}$ & 1 \\
Esterase & Est & 3.1 .1 .1 & 6 & 1 \\
Fructose-1,6-diphosphatase & f1,6dp & 3.1 .3 .11 & $11, \mathrm{M}$ & 1 \\
Isocitrate dehydrogenase & Idh & 1.1 .1 .42 & $1,11, \mathrm{M}$ & 1 \\
Leucine-aminopeptidase & Lap & $3.4 .11 .-$ & 6,8 & 2 \\
Malate dehydrogenase & Mdh & 1.1 .1 .37 & $11, \mathrm{M}$ & 2 \\
Malic enzyme & Me & 1.1 .1 .40 & 11 & 1 \\
Phosphoglucomutase & Pgm & 2.7 .5 .1 & 6 & 1 \\
6-phosphoglucodehydrogenase & 6-pgd & 1.1 .1 .44 & $\mathrm{M}$ & 1 \\
Shikimate dehydrogenase & Skdh & 1.1 .1 .25 & $\mathrm{M}$ & 1 \\
TOTAL LOCI & & & & 12 \\
\hline
\end{tabular}

${ }^{\mathrm{a} E n z y m e ~ c o m m i s s i o n ~ n u m b e r ~}$

bystems 6,8,11 after Soltis et al. (1983); system M, a 7.5 pH version of the morpholine citrate system after Odrzykoski and Gottlieb (1984).

expected heterozygosity $\left(\mathrm{H}_{\mathrm{e}}\right)$, polymorphic index $(\mathrm{PI}=$ mean proportion of polymorphic loci), mean number of alleles per locus (A), and fixation index (f). We performed a Fisher shuffling test (exact test) of H-W disequilibrium (Fisher 1935, Haldane 1954) for each locus and each study population using GDA (Lewis and Zaykin 2001).

The distribution of genetic variation among the J. osteosperma populations was also determined using GDA. The following F-statistics were calculated: $\mathrm{F}_{\mathrm{IS}}, \mathrm{F}_{\mathrm{IT}}$, and $\mathrm{F}_{\mathrm{ST}}$ (Wright 1921, 1943, Weir 1996, Hartl and Clark 1997). For this study, $\mathrm{F}_{\mathrm{IS}}$ and $\mathrm{F}_{\mathrm{IT}}$ were computed using GDA. We calculated $\mathrm{F}_{\mathrm{ST}}$ among the populations following Wright (1943).

To further assess the genetic interaction among populations, gene flow $(\mathrm{Nm}=$ effective number of migrants per generation) was calculated using methods of Wright (1943; $\mathrm{Nm}=$ $\left.\left[1-\mathrm{F}_{\mathrm{ST}}\right] / 4 \cdot \mathrm{F}_{\mathrm{ST}}\right)$. We computed Nei's (1978) genetic distance for each population and generated a cluster phenogram of the genetic distance matrix among populations using the unweighted pair group method of averaging (UPGMA) and GDA software. We also performed a Mantel matrix randomization test (Mantel 1967) to determine if there was a significant relationship between geographic distance and genetic distance (Rohlf 1992).

We ran linear regressions (using population means for reproductive data averaged across the 2 years of sampling) to determine if any correlations existed between genetic variation (observed heterozygosity) and reproductive success (S/O, proportion seed abortion, proportion seed parasitism). Regressions were performed using SYSTAT 9.

\section{Results}

Population Density and Age Structure

Density (individuals $\cdot \mathrm{km}^{-2}$ ) varied among study populations. The Valley population was significantly more dense ( $\geq 3$ times more dense) than all other populations $(28.4$ individuals . $\mathrm{km}^{-2}$; Table 1). The 2 smallest populations at DPG were the least dense (Granite: 4.8 individuals $\cdot \mathrm{km}^{-2}$; Dune: 6.4 individuals $\cdot \mathrm{km}^{-2}$; Table 1). The 3 DPG populations had fewer seedlings and a greater proportion of adults compared to the nonisolated populations (Table 1).

\section{Reproductive Success}

SeEd-Per-ovule Ratio.-Populations differed for $\mathrm{S} / \mathrm{O}$ ratios $(P=0.000$; Table 3$)$. Specifically, the Valley and Nephi (nonisolated) populations had higher $\mathrm{S} / \mathrm{O}$ ratios (almost 2fold higher) than the isolated DPG populations (Table 3) in both 2000 and 2001. The S/O ratios decreased (by $\sim 7 \%-56 \%$ ) over the 2 collection years in all study populations $(P=$ 0.007; Table 3). Furthermore, the interaction between population and year was also significant $(P=0.000)$. We found no correlation between stand density and $\mathrm{S} / \mathrm{O}\left(r^{2}=0.351, P=\right.$ $0.394)$.

SeEd Parasitism.-Populations varied for seed parasitism by larval insects $(P \leq 0.0005$, range 1\%-50\%; Table 3). The Granite and Cedar populations at DPG exhibited the highest percentage of seeds parasitized. However, seed parasitism at the Dune population was not significantly different from the nonisolated 
TABLE 3. Reproductive results indicating significant differences in $S / O$ ratios, proportion insect parasitism of seeds, and proportion seed abortion in Utah juniper populations. Means in a column that share the same letter within a year do not differ significantly at $P \leq 0.05$. Each year is considered separately in this table and is thus represented by a different suite of letters.

\begin{tabular}{lllcc}
\hline Population & Year & S/O ratio & Parasitized seed & Aborted seed \\
\hline Granite & 2000 & $0.276 \mathrm{a}$ & $0.526 \mathrm{a}$ & $0.228 \mathrm{a}$ \\
Cedar & 2000 & $0.447 \mathrm{~b}$ & $0.307 \mathrm{~b}$ & $0.261 \mathrm{a}$ \\
Dune & 2000 & $0.355 \mathrm{~b}$ & $0.098 \mathrm{c}$ & $0.562 \mathrm{~b}$ \\
Valley & 2000 & $0.743 \mathrm{c}$ & $0.104 \mathrm{c}, \mathrm{d}$ & $0.130 \mathrm{a}$ \\
Nephi & 2000 & $0.654 \mathrm{c}$ & $0.150 \mathrm{~d}$ & $0.232 \mathrm{a}$ \\
Mean & 2000 & 0.495 & 0.237 & 0.283 \\
Granite & 2001 & $0.178 \mathrm{f}$ & $0.321 \mathrm{f}$ & $0.498 \mathrm{f}$ \\
Cedar & 2001 & $0.417 \mathrm{~g}$ & $0.515 \mathrm{~g}$ & $0.061 \mathrm{~g}$ \\
Dune & 2001 & $0.196 \mathrm{f}$ & $0.293 \mathrm{f}$ & $0.510 \mathrm{f}$ \\
Valley & 2001 & $0.416 \mathrm{~g}, \mathrm{~h}$ & $0.194 \mathrm{~h}$ & $0.379 \mathrm{~h}$ \\
Nephi & 2001 & $0.488 \mathrm{~h}$ & $0.266 \mathrm{f}$ & $0.247 \mathrm{i}$ \\
MEAN & 2001 & 0.339 & 0.318 & 0.328 \\
\hline
\end{tabular}

TABLE 4. Descriptive statistics of genetic variability within Utah juniper populations.

\begin{tabular}{lccccc}
\hline Population & $\begin{array}{c}\text { Mean observed } \\
\text { heterozygosity }\left(\mathrm{H}_{\mathrm{o}}\right)\end{array}$ & $\begin{array}{c}\text { Mean expected } \\
\text { heterozygosity }\left(\mathrm{H}_{\mathrm{e}}\right)\end{array}$ & $\begin{array}{c}\text { Polymorphic } \\
\text { index }(\mathrm{P})\end{array}$ & $\begin{array}{c}\text { Mean number of } \\
\text { alleles/locus }(\mathrm{A})\end{array}$ & $\begin{array}{c}\text { Fixation } \\
\text { index }(\mathrm{f})\end{array}$ \\
\hline Granitea $^{\mathrm{a}}$ & 0.140 & 0.441 & 1.00 & 2.92 & 0.686 \\
Cedara $^{\mathrm{a}}$ & 0.171 & 0.359 & 1.00 & 2.83 & 0.527 \\
Dune $^{\mathrm{a}}$ & 0.094 & 0.393 & 1.00 & 2.83 & 0.764 \\
Valley $_{\text {Nephi }}$ & 0.307 & 0.504 & 1.00 & 2.83 & 0.394 \\
ALL POPULATIONS & 0.256 & 0.477 & 1.00 & 2.92 & 0.466 \\
& 0.194 & 0.435 & 1.00 & 2.87 & 0.558 \\
\hline
\end{tabular}

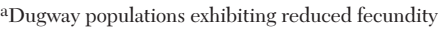

populations. Seed parasitism also varied between years $(P \leq 0.0005)$. For example, seeds from the Granite population were heavily parasitized in $2000(53 \%)$ but less parasitized in $2001(32 \%)$. The Cedar population (DPG population) was also highly parasitized but exhibited the opposite pattern (31\% in 2000 and $52 \%$ in 2001). Thus, the interaction between population and year was significant for percent seed parasitized $(P \leq 0.0005)$. In addition, we found no relationship between stand density and seed parasitism $\left(r^{2}=0.232, P=0.412\right)$.

SEED ABORTION.-We observed differences among populations for percent seed aborted $(P$ $\leq$ 0.0005; Table 3). The Dune population at DPG exhibited the highest seed abortion rates (56\% in 2000 and $50 \%$ in 2001; Table 3). The nonisolated populations, Valley and Nephi, had significantly lower seed abortion over the 2 collection years (Table 3). We observed differences among years for percent seed aborted $(P$ $\leq 0.0005)$ and an interaction between population and year $(P \leq 0.0005)$. Percent seed abortion significantly increased (about 2-fold) in the Granite population from 2000 to 2001, while it decreased in the Cedar population between years. In addition, we found no significant correlation between stand density and percent seed aborted $\left(r^{2}=0.008, P=0.888\right)$.

\section{Allozyme Data}

GENETIC VARIATION WITHIN POPULATIONS.Genetic diversity statistics for each of the studied populations are summarized in Table 4 . The 2 nonisolated populations had the highest observed heterozygosity $\left(\mathrm{H}_{\mathrm{o}}\right)$ of the 5 juniper populations we studied (Table 4). The 3 Dugway populations had significantly lower genetic variability. Of the 3 Dugway populations, Cedar, the largest and least fragmented population, was the most variable $\left(\mathrm{H}_{\mathrm{O}}=0.171\right)$. The Dune population, the smallest population, was the least genetically variable $\left(\mathrm{H}_{\mathrm{O}}=0.094\right.$; Table 4).

For each of the 5 juniper populations, the proportion of polymorphic loci (P) was 1.0. Thus, all 12 loci had allelic variability in each of the sampled populations. The mean number 
TABLE 5. $P$-values for a Fisher's shuffling test of Hardy-Weinberg disequilibrium (Fisher 1935, Haldane 1954) for each Utah juniper population and locus generated using GDA. Significance was determined at $P \leq 0.05$.

\begin{tabular}{lccccc}
\hline & \multicolumn{5}{c}{ Population } \\
\cline { 2 - 5 } Locus & Granite $^{\mathrm{a}}$ & Cedar $^{\mathrm{a}}$ & Dune $^{\mathrm{a}}$ & Valley & Nephi \\
\hline Me-1 & 0.000 & 0.000 & 0.000 & 0.000 & 0.000 \\
Lap-1 & 0.000 & 0.000 & 0.000 & 0.000 & 0.000 \\
Lap-2 & 0.000 & 0.000 & 0.000 & 0.014 & 0.000 \\
Idh-1 & 0.000 & 0.001 & 0.000 & 0.000 & 0.000 \\
6pgd-1 & 0.000 & 1.000 & 0.041 & 0.181 & 1.000 \\
Skdh-1 & 0.001 & 0.000 & 0.241 & 0.556 & 0.032 \\
Pgm-1 & 0.000 & 0.106 & 0.000 & 0.001 & 0.043 \\
Mdh-1 & 0.005 & 0.014 & 0.000 & 0.013 & 0.010 \\
Mdh-2 & 0.000 & 0.000 & 0.000 & 0.001 & 0.000 \\
Ald-1 & 0.000 & 0.001 & 0.000 & 0.712 & 0.009 \\
fl6dp-1 & 0.000 & 1.000 & 0.000 & 0.002 & 0.002 \\
Est-1 & 0.038 & 0.002 & 0.000 & 0.001 & 1.000 \\
\hline
\end{tabular}

a Located at Dugway Proving Ground, Utah

of alleles per locus (A) was 2.83 for the DPG populations, and it was slightly higher for the nonisolated populations (A = 2.92; Table 4).

DeVIaTion From Hardy-Weinberg EXPECTATIONS.—Expected heterozygosity $\left(\mathrm{H}_{\mathrm{e}}\right)$ was lower than observed heterozygosity for each juniper population (Table 4). The smallest populations at DPG, Granite and Dune, exhibited the largest deviations from $\mathrm{H}-\mathrm{W}$ expectations. The Granite population exhibited significant $\mathrm{H}-\mathrm{W}$ disequilibrium at all surveyed loci (Table 5). The Dune population showed significant $\mathrm{H}-\mathrm{W}$ disequilibrium at 11 of the 12 loci surveyed, and Cedar at 9 loci. However, the nonisolated populations also deviated significantly from $\mathrm{H}-\mathrm{W}$ expectations for most loci (Valley at 9 loci and Nephi at 10 loci; Table 5).

The estimate of the fixation index (f) was lower for the control populations than for the DPG populations (Table 4). The fixation index was lowest for the Valley control population ( $f$ $=0.394)$. The 2 smallest populations, which were at DPG, had the highest fixation indices (Dune $f=0.763$ and Granite $f=0.686$; Table 4). However, all populations exhibited fixation indices $>0$. The mean value of $\mathrm{F}_{\mathrm{IS}}$ across all 12 loci was 0.566 . This positive value indicates that there were fewer heterozygotes than expected within each of the populations (Table 6).

GENETIC VARIATION AMONG POPULATIONS.The mean $\mathrm{F}_{\text {IT }}$ was 0.597 for these populations, indicating that there are fewer heterozygotes than expected among the study populations (Table 6). The mean $\mathrm{F}_{\mathrm{ST}}$ was 0.071 , indicating that the degree of genetic differentiation among
TABLE 6. F statistics for individual loci of Utah juniper.

\begin{tabular}{lcc}
\hline Locus & $F_{\text {IS }}$ & $F_{\text {IT }}$ \\
\hline Me-1 & 0.705 & 0.740 \\
Lap-1 & 0.682 & 0.701 \\
Idh-1 & 0.709 & 0.712 \\
6pgd-1 & 0.201 & 0.348 \\
Skdh-1 & 0.216 & 0.237 \\
Pgm-1 & 0.473 & 0.471 \\
Mdh-1 & 0.533 & 0.596 \\
Mdh-2 & 0.770 & 0.805 \\
Ald-1 & 0.514 & 0.564 \\
f1,6dp-1 & 0.702 & 0.749 \\
Lap-2 & 0.519 & 0.525 \\
Est-1 & 0.298 & 0.311 \\
OvERALL & 0.566 & 0.597 \\
\hline
\end{tabular}

the populations was moderate (Wright 1951). The estimated rate of gene flow $(\mathrm{Nm})$, computed using $\mathrm{F}_{\mathrm{ST}}$, among the sampled populations was high for J. osteosperma $(\mathrm{Nm}=2.52$ migrants per generation).

Nei's (1978) genetic distances (D) ranged from 0.007 to 0.152 , and geographic distances ranged from 10,393 $\mathrm{m}$ to $584,942 \mathrm{~m}$ (Table 7). The Mantel matrix randomization test showed no relationship between geographic and genetic distance among populations $\left(r^{2}=0.004, P=\right.$ $0.863)$.

While no relationship existed between geographic and genetic distance, the DPG populations appeared more closely related to one another than to the 2 nonisolated comparative populations (Fig. 2). In the UPGMA cluster phenogram, which was generated from genetic 
TABLE 7. Geographic distances and genetic distances between sampled populations of Utah juniper. Geographic distances $(\mathrm{m})$ are given above the diagonal, and Nei's (1972) genetic distances (D) are given below the diagonal.

\begin{tabular}{lccccc}
\hline Populations & Granite & Cedar & Dune & Valley & Nephi \\
\hline Granite & - & 33134.2 & 37683.3 & 59661.4 & 284921.4 \\
Cedar & 0.059 & - & 22279.8 & 31785.9 & 257045.9 \\
Dune & 0.008 & 0.063 & - & 24234.5 & 249494.5 \\
Valley & 0.062 & 0.152 & 0.092 & - & 0.048 \\
Nephi & 0.060 & 0.127 & 0.078 & - \\
\hline
\end{tabular}

distances, the 3 DPG populations clustered together (Fig. 2).

RELATIONSHIP BETWEEN GENETIC AND REPRODUCTIVE DATA.-We found a significant relationship between genetic variation and reproductive success. Mean observed heterozygosity was positively correlated with $\mathrm{S} / \mathrm{O}$ ratios for both years of the study (2000: $r^{2}=$ 0.892, $P \leq 0.05$; 2001: $\left.r^{2}=0.632, P \leq 0.05\right)$. Each data point in the analysis represents a mean $\mathrm{S} / \mathrm{O}$ ratio for the sampled individuals in each study population. We found a negative correlation between observed heterozygosity and percent seed abortion in $2000\left(r^{2}=0.624\right.$, $P<0.01)$, but no relationship in $2001\left(r^{2}=\right.$ $0.098, P=0.607$ ). However, we found no relationship between observed heterozygosity and percent insect parasitism of seeds $\left(r^{2}=0.218\right.$, $P=0.427)$.

\section{Discussion}

Reproductive success varied significantly among study populations. Specifically, S/O ratios were significantly lower in the isolated populations than in the nonisolated populations (with the exception of the largest DPG population, Cedar, in 2001). Moreover, the DPG populations exhibited $\mathrm{S} / \mathrm{O}$ ratios at or significantly below the average for woody perennial plant species (0.327; Wiens 1984). The nonisolated encroaching Utah juniper populations exhibited S/O ratios much higher than average for woody perennials (Wiens 1984, Wiens et al. 1987). Unusually high $\mathrm{S} / \mathrm{O}$ ratios in these large, nonisolated populations might contribute to their success and ability to encroach.

Low S/O ratios in the DPG populations were primarily due to high degrees of insect parasitism of seeds and/or high levels of abortion in developing seeds. Both environmental and genetic factors may contribute to high seed abortion and/or seed parasitism in natural populations of conifers and other woody perennials (Carter 1939, DeBarr 1957, Hard 1963, Crane 1964, Krugman 1966, Dickmann and Kozlowski 1969, Bollard 1970, Goyer and Nachod 1976, Mattson 1978, Stephenson 1980, 1981, Bunderson 1983, Levin 1984, Wiens et al. 1987, Nakamura 1988, Charlesworth 1989, Oritz et al. 1998, Daehler 1999, Sorenson 1999, Garcia et al. 2000). Although this study focused primarily on genetic factors rather than environmental factors, we did show significant differences in reproductive data between the 2 years of our study. Specifically, all study populations but the Cedar population exhibited reduced reproductive success in 2001. In some populations, this reduction was due to an increase in seed abortion, while in others it was due to increased insect parasitism of seeds.

Precipitation might explain the decrease in reproductive success that we observed between years. Annual precipitation was higher at DPG in the year $2000(21.9 \mathrm{~cm})$ than in $2001(5.45$ $\mathrm{cm}$; U.S. Army unpublished data, weather station at DPG). This difference in annual precipitation was partly due to high precipitation during the month of February 2000. Late winter and/or early spring precipitation might be particularly important for seed production in Utah juniper because this is the time when seeds are maturing on the trees.

Other environmental factors (i.e., light, water, soil nutrients, temperature, etc.) might affect the amount of insect parasitism of seeds in a population (Bunderson 1983, Cates and Redak 1986, Cochran 1998, Garcia 1998, Garcia et al. 2000). In a study of $17 \mathrm{~J}$. osteosperma sites, Bunderson (1983) found a positive correlation between insect parasitism and higher levels of phosphorous and magnesium in the soil. However, Bunderson demonstrated that increased parasitism of Utah juniper seeds could not be explained by environmental factors alone (Bunderson 1983). 


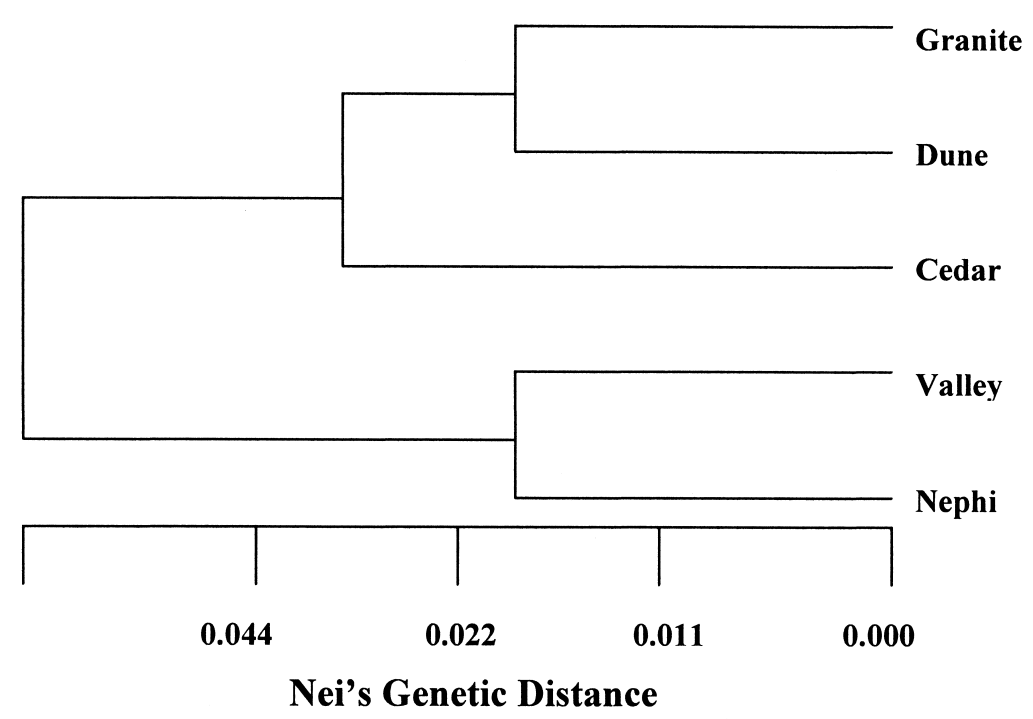

Fig. 2. UPGMA cluster phenogram showing genetic relationships of sampled populations based upon Nei's (1978) genetic distances among populations calculated by GDA, using allele frequencies computed from $\sim 40$ randomly sampled individuals in each study population.

The influence of environmental factors on seed set in the Utah juniper was not the focus of our study and merits further examination. Yet it is difficult to explain high levels of abortion with environmental factors alone, since the Dune population suffers greatly from abortion but has a very similar environment to other DPG populations. These data are consistent with other studies that have demonstrated a lack of correlation between resource availability and embryo abortion (Wiens et al. 1987, Lalonde and Roitberg 1989, 1994, Herrera 1991, Allphin et al. 2002, Wiens et al. 2002).

Studies of other conifers have suggested a relationship between susceptibility to insect parasitism and stand density (Ferrell et al. 1933, White 1974, Sturgeon 1979, Gambliel and Croteau 1984, Horner et al. 1987, Cochran 1998). Some have suggested that insect parasites are better able to track their hosts in less dense populations (Fauss and Pierce 1969, Sturgeon 1979) while others argue that tree age is a factor of resistance (Kennedy and Booth 1951, Dickman 1978, Wagner et al. 1989). However, in this study, we found no correlation between juniper stand density and predispersal insect parasitism of seeds. Though this find is interesting, we recognize the lack of robustness for this regression due to the small sample size.
Stand density has also been shown to affect fruit set and pollination success in conifers (Arista and Talvera 1994, 1996, Oritz et al. 1998). However, we found no significant relationship between stand density and S/O ratio or percent seed abortion. Therefore, stand density does not likely explain our observed patterns of reproductive success in isolated populations of Utah juniper at DPG. Once again, we recognize that the lack of relationship might be a consequence of the small number of stands measured.

Because we found a significant relationship between observed heterozygosity and both $\mathrm{S} / \mathrm{O}$ ratio and percent seed abortion, low reproductive success in the isolated populations of Utah juniper at DPG might also be explained by genetics. Populations at Dugway have been historically isolated and are becoming increasingly more isolated from one another because of fire. We found that the 3 isolated Dugway populations have lower genetic variability than the nonisolated comparative populations. The DPG populations also exhibited higher fixation (f) indices than the nonisolated populations.

However, all the Utah juniper populations in this study exhibited significant deviations from Hardy-Weinberg equilibrium at most loci. Moreover, all the populations had lower 
observed heterozygosity $\left(\mathrm{H}_{\mathrm{o}}\right)$ than $\mathrm{H}-\mathrm{W}$ expected heterozygosity $\left(\mathrm{H}_{\mathrm{e}}\right)$. Because the observed heterozygosity in the populations is less than predicted, it may be assumed that the populations are increasing in homozygosity, a characteristic of inbred mating systems. Populations that become progressively fragmented until they are isolated from one another may ultimately lose genetic variability (Wright 1943, Loveless and Hamrick 1984, Barrett and Kohn 1991, Godt et al. 1995, Allphin et al. 1998, Allphin and Windham 2002). Therefore, inbreeding due to isolation could result in the lower heterozygosity that we observed for the DPG populations.

The DPG populations typically exhibit significantly higher seed abortion rates than the nonisolated populations. Low reproductive success due to high abortion in DPG populations might be explained by inbreeding/genetic load (Wiens 1984, Wiens et al. 1987). Because outcrossing species, like Utah juniper, are able to maintain more potentially-lethal alleles in the heterozygous state (genetic load), inbreeding in isolated/fragmented populations may cause the frequency of homozygote combinations of lethal alleles to increase (Hardon 1961, Sorenson 1969, Levin 1984, Wiens 1984, Wiens et al. 1987, Nickrent and Wiens 1989, Allphin et al. 2002).

Reduced seed set in the isolated populations at DPG may be a result of low genetic diversity and inbreeding (familial breeding) in these small populations (Ellstrand and Elam 1993, Godt et al. 1997). The positive correlation between reproductive success (seed per ovule) and genetic variability in both years of the study supports this idea. The Dune population has the lowest $\mathrm{H}_{0}$, the highest $\mathrm{f}$, and the highest percentage of aborted seed of the studied populations. Dune also exhibits the highest percentage of aborted seed and is currently the smallest and 1 of the least dense of all the sampled populations. Therefore, the effects of low genetic diversity are likely most pronounced in the Dune population because of its small size.

The Granite and Cedar populations also have low genetic diversity and low population reproductive success. In the Granite population, these results might also be a consequence of small population size and low population density. However, the Cedar population is still large and relatively dense. Moreover, this population has the highest reproductive success of the 3. It is also important to note that it is difficult to establish the true number of aborted seeds in the Granite and Cedar populations because of their higher parasitism rates. It is likely that many of the aborted seeds in these populations were categorized as parasitized because it was impossible to differentiate if a parasitized seed was once viable or if it was a late abortion.

Loss of genetic variability also often results in a loss of resistance to a variety of insects and other pathogens (Eidt and MacGillivary 1972, McDonald 1985, Cates and Redak 1986, Barret and Kohn 1991). The lack of correlation between heterozygosity and insect parasitism of seeds in our study populations is primarily due to the high level of abortion in the Dune population. If this population is removed from the analysis, there is a significant correlation over both years of our study $\left(r^{2}=0.877 ; P<\right.$ $0.01)$. Therefore, high predispersal insect parasitism of seeds might also be explained by a loss of genetic variability in small, isolated populations of Utah juniper. However, the Cedar population has higher levels of parasitism than expected for a relatively large, dense population. We suggest that this population may be experiencing genetic drift due to its relative isolation, and it is thus beginning to lose resistance to insect parasitism as it loses genetic diversity.

The historical genetic diversity and the degree of historical isolation of these populations are unknown. We note that historical, long-term isolation of these populations might best explain the loss of reproductive success and genetic variability in these populations. Moreover, little is known regarding the distance of pollen dispersal and seed dispersal in this species. Dispersal factors might also play a role in the degree of isolation in these stands. Additional study will be necessary to examine how dispersal and long-term isolation contribute to low reproductive success and genetic diversity in Utah juniper at DPG.

Low genetic diversity for DPG populations might also be explained by a more recent founder event (invasion) of Utah juniper into a marginal, more ephemeral habitat at DPG. These populations appear to be at the westernmost extension of the species' range in Utah 
TABLE 8. Levels of allozyme variation at the species level for species with different characteristics or categories. The data on broad categories were extracted from Hamrick and Godt (1990). The data for Juniperus rigida and J. coreana were extracted from Huh and Huh (2000). Means followed by the same letter in a column do not differ significantly at P $\leq 0.05$. Standard errors are in parentheses.

\begin{tabular}{|c|c|c|c|c|c|c|}
\hline Categories & $N^{*}$ & $\begin{array}{l}\text { Mean no. of } \\
\text { populations }\end{array}$ & $\begin{array}{l}\text { Mean no. } \\
\text { of loci }\end{array}$ & $\mathrm{P}_{\mathrm{s}}^{\dagger}$ & $\mathrm{A}_{\mathrm{s}}^{\ddagger}$ & $\mathrm{H}_{\mathrm{es}}^{\S}$ \\
\hline Gymnosperms & 55 & $8.5(0.9)$ & $16.1(1.3)$ & $70.9(3.6) \mathrm{a}$ & $2.35(0.12) \mathrm{a}$ & $0.173(0.011) \mathrm{a}$ \\
\hline $\begin{array}{l}\text { Long-lived woody } \\
\text { perennials }\end{array}$ & 110 & $9.3(1.4)$ & $17.0(0.9)$ & $64.7(2.7) \mathrm{a}$ & $2.19(0.09) \mathrm{a}$ & $0.177(0.010) \mathrm{a}$ \\
\hline Regional species & 193 & $10.4(1.1)$ & $16.7(0.7)$ & $52.9(2.1) \mathrm{ab}$ & $1.94(0.06) \mathrm{b}$ & $0.150(0.008) b$ \\
\hline Widespread species & 105 & $25.5(5.2)$ & $14.6(0.9)$ & $58.9(3.1) \mathrm{a}$ & $2.29(0.13) \mathrm{a}$ & $0.202(0.015) \mathrm{a}$ \\
\hline $\begin{array}{l}\text { Outcrossing wind- } \\
\text { pollinated species }\end{array}$ & 105 & $10.7(1.6)$ & $16.7(0.9)$ & $66.1(2.7) \mathrm{a}$ & $2.40(0.13) \mathrm{a}$ & $0.162(0.0009) \mathrm{ab}$ \\
\hline Juniperus rigida & - & 12 & 22 & $72.7(0.029)$ & $2.63(0.002) \mathrm{c}$ & $0.224(0.00) \mathrm{c}$ \\
\hline Juniperus coreana & - & 6 & 22 & $54.6(0.006)$ & $2.42(0.005) \mathrm{ac}$ & $0.199(0.00) \mathrm{a}$ \\
\hline Juniperus osteosperma & - & 6 & 12 & 100 & $2.87(0.002) \mathrm{c}$ & $0.435(0.003) \mathrm{d}$ \\
\hline
\end{tabular}

Percentage polymorphic loci

\#Number of alleles per locus

$\S$ Expected H-W diversity or genetic diversity

(Fig. 1). However, further genetic studies need to be performed in a broader geographic context to explore this hypothesis.

While many genetic diversity studies have been conducted on conifers in the family Pinaceae, few have been conducted in the family Cupressaceae (Nowak et al. 1994, Zhang et al. 1997, Huh and Huh 2000, Terry et al. 2000a, Van der Merwe et al. 2000). However, we compared our genetic diversity data for Utah juniper with a synthesis paper by Hamrick and Godt (1990), which summarized levels of diversity across a wide sampling of gymnosperms and other plant species with similar life history traits. In addition, we compared our allozyme data with data observed for 2 other juniper species (Table 8; Huh and Huh 2000).

Our populations of Utah juniper exhibited a higher percentage of polymorphic loci than that observed for other gymnosperms, longlived woody perennials, regional plant species, widespread plant species, outcrossing windpollinated species, or other junipers (Table 8). However, J. rigida and other gymnosperms were highly polymorphic. Our sampled populations of Utah juniper had a significantly higher mean number of alleles per locus than other gymnosperms and woody perennials, but they had values of the mean number of alleles per locus that were consistent with other junipers (Table 8; Hamrick and Godt 1990, Huh and Huh 2000). Finally, our Utah juniper populations had significantly higher genetic diversity $\left(\mathrm{H}_{\mathrm{es}}\right)$ than the other junipers, gymnosperms, and species with similar life histories (Table 8; Hamrick and Godt 1990, Huh and Huh 2000). We make general comparisons among allozyme data between similar species and note the inherent problems due to variation in loci analyzed for each species (see Hamrick and Godt 1990).

For Utah juniper in this study, the $\mathrm{F}_{\mathrm{ST}}$ was 0.071 , which indicated moderate genetic differentiation among populations (Wright 1943). Other wind-pollinated, long-lived, conifer populations exhibit $\mathrm{F}_{\mathrm{ST}}$ values higher than our Utah juniper populations (Hamrick and Godt 1996). For example, $\mathrm{F}_{\mathrm{ST}}$ values obtained for pine species in conservation studies range between 0.161 and 0.300 (Conckle 1981, Schiller et al. 1985, Hamrick et al. 1994).

Estimated gene flow among these Utah juniper populations was relatively high $(\mathrm{Nm}=$ 2.52). However, some conifer species have shown even higher rates of gene flow $(\mathrm{Nm}=$ 4.48; Parker et al. 1997). Although there was a moderately high estimate of gene flow between populations of the juniper based upon genetic distances, we could find no correlation between geographic and genetic distance in this species. This is not as expected under the isolation-bydistance model (Wright 1943, 1946). One might expect a lack of correlation between geographic and genetic distance if panmixia (or regular random mating) were occurring among populations (Wright 1946). This explanation seems unlikely for these populations of Utah juniper because of the historical isolation and 
long distances separating many of these populations. Yet Lyford et al. (2003) has suggested that historically, populations of Utah juniper became established through long-distance dispersal events.

We suggest that Nm may not be reflective of actual gene flow events in the juniper, but possibly reflective of alleles shared through common ancestry or historic gene flow events. We used a variant of $\mathrm{F}_{\mathrm{ST}}$ to estimate $\mathrm{Nm}$. Though studies have shown $\mathrm{F}_{\mathrm{ST}}$ to be an excellent measure of the extent of population structure, it is rare that $\mathrm{F}_{\mathrm{ST}}$ can be translated into accurate $\mathrm{Nm}$ estimates (Whitlock and McCauley 1999). Therefore, low $\mathrm{F}_{\mathrm{ST}}$ values among DPG populations may be responsible for the high Nm estimates, rather than actual migration between the DPG populations (Whitlock and McCauley 1999). Moreover, our lack of correlation between geographic and genetic distance might be a consequence of our limited data set with its limited range of distances among populations.

The findings of this study serve to compare only the 3 stagnant DPG populations with 2 continuous, encroaching Utah juniper populations. However, more information regarding the historical isolation of the DPG population is needed to aid data interpretation. Moreover, we included only 2 years of reproductive data in our analysis. Considering that this study occurred over abnormally dry years for DPG, additional years of reproductive data would provide more insight into the role of fecundity for long-term persistence of these juniper stands. Therefore, to provide a more definitive statement on the role of habitat fragmentation and isolation in the loss of reproductive success of Utah juniper populations, additional studies should be conducted on isolated populations and encroaching populations across the western U.S., over multiple years and across varying environmental regimes.

\section{Conclusions}

The populations at Dugway have been historically separated by elevation and distance, but they are becoming progressively fragmented as a result of fire. As populations become fragmented, there is an increased chance that gene flow will be reduced and that inbreeding may occur. The 3 Utah juniper populations located at Dugway appear to be suffering from reduced seed set and a loss of genetic variability compared to the control populations.

These data have important implications for conservation officials and land managers. Management decisions regarding Utah juniper typically deal with the control of its encroachment. However, we have demonstrated some of the long-term effects of isolating populations of Utah juniper. Land managers should be careful to prevent isolation and maintain gene flow to preserve reproductive success and long-term persistence of Juniperus osteosperma, particularly at DPG.

\section{ACKNOWLEDGMENTS}

We thank Chad Horman, Jason Scott, Duane Smith, Robert Johnson, and Brad Jessop for assistance with field data collection. We also thank Heidi Christy and Jill Johnstone for assistance with genetic analyses. We also thank Aimee Hall, Rebecca Rendón, and Janene Auger for editorial assistance and Mark Belk, Kent Hatch, and Steve Peck for valuable discussions and suggestions regarding this manuscript. This research was conducted with the financial support of the U.S. Army Integrated Training Area Management Program, Dugway Proving Ground, Utah, and the Department of Integrative Biology at Brigham Young University, Provo, Utah.

\section{Literature Cited}

Allphin, L., D. Wiens, And M. Windham. 2002. The relative effects of resources and genetics on reproductive success in the rare Kachina daisy, Erigeron kachinensis (Asteraceae). International Journal of Plant Sciences 163:599-612.

AllPhin, L., AND M. Windham. 2002. Morphological and genetic variation among populations of the rare Kachina daisy (Erigeron kachinensis) from southeastern Utah. Western North American Naturalist 62: 423-436.

Allphin, L., M. Windham, and K.T. Harper. 1998. Genetic diversity and gene flow in the endangered dwarf bear poppy, Arctomecon humilis (Papaveraceae). American Journal of Botany 85:1251-1261.

Arista, M., and S. TAlavera. 1994. Pollen dispersal capacity and pollen viability of Abies pinsapo Bois. Silvae Genetica 43:155-158.

1996. Density effect on the fruit-set, seed crop viability and seedling vigour of Abies pinsapo. Annals of Botany 77:187-192.

ARo, R.S. 1971. Evaluation of pinyon-juniper conversion to grassland. Journal of Range Management 24:188197.

BarretT, S.C., And J.R. Kohn. 1991. Genetic and evolutionary consequences of small population size in 
plants: implications for conservation. Pages 3-30 in D.A. Falk and K.E. Holsinger, editors, Genetics and conservation of rare plants. Oxford University Press, New York.

Betancourt, J.L. 1987. Paleoecology of pinyon-juniper woodlands: summary. Pages 129-139 in R.L. Everett, editor, Proceedings—pinyon juniper conference. General Technical Report INT-215, USDA Forest Service, Intermountain Research Station, Ogden, UT.

Blackburn, W.H., and P.T. Tueller. 1970. Pinyon and juniper invasion in blackbrush communities in eastcentral Nevada. Ecology 51:841-848.

Bollard, E.G. 1970. The physiology and nutrition of developing fruits. Pages 387-427 in A.C. Hulme, editor, The biochemistry of fruits and their products. Volume 1. Academic Press, New York.

Bunderson, E.D. 1983. Autecology of Juniperus osteosperma in seventeen Utah sites. Doctoral dissertation, Brigham Young University, Provo, UT.

Bunting, S.C., B.M. Kilgore, and C.L. Bushey. 1987. Guidelines for prescribed burning sagebrush-grass rangelands in the northern Great Basin. General Technical Report INT-231:33, USDA Forest Service, Intermountain Forest and Range Experiment Station.

Byth, K., AND B.D. RIPLEy. 1980. On sampling spatial patterns by distance methods. Biometrics 36:279-284.

Carter, W. 1939. Injuries to plants caused by insect toxins. Botany Review 5:273-326.

Cates, R.G., AND R. REDAK. 1986. Between-year population variation in resistance of Douglas-fir to the western spruce budworm. American Chemical Society Symposium Series 296:106-115.

Charlesworth, D. 1989. Evolution and a low fertility in plants: pollen limitation, resource allocation, and genetic load. Trends in Ecology and Evolution 4: 289-292.

Charlesworth, D., AND B. Charlesworth. 1987. Inbreeding depression and its evolutionary consequences. Annual Review of Ecology and Systematics 18: 237-268.

Clark, W.P., M.B. Baker, and P.F. O’Connell. 1974. Effects of pinyon-juniper removal on natural resource products and uses in Arizona. Research Paper RM128, USDA Forest Service, Rocky Mountain Forest and Range Experiment Station, Fort Collins, CO.

Cochran, P.H. 1998. Examples of mortality and reduced annual increments of white fir induced by drought, insects, and disease at different stand densities. USDA Forest Service, Pacific Northwest Research Station, Portland, OR.

CONCKLE, M.T. 1981. Isozyme variation and linkage in six conifer species. Pages 11-17 in M.T. Conckle, editor, Proceedings of the symposium on isozymes of North American forest trees and forest insects. General Technical Report PSW 48, USDA Forest Service, Pacific Southwest Forest and Range Experiment Station, Berkeley, CA.

Cottom, G., and J.T. Curtis. 1956. The use of distance measures in phytosociological sampling. Ecology 37: 451-460.

Covington, W.W., and L.F. Debano. 1990. Effects of fire on pinyon-juniper soils. Pages 78-86 in J.S. Krammes, technical coordinator, Effects of fire management of southwestern natural resources: proceedings of the symposium; 1998 November 15-17; Tucson, Arizona. General Technical Report RM-191, USDA Forest
Service, Rocky Mountain Forest and Range Experiment Station, Fort Collins, CO.

Crane, J.C. 1964. Growth substances in fruit setting and development. Annual Review of Plant Physiology 15:303-326.

DAEhler, C.C. 1999. Inbreeding depression in smooth cordgrass (Spartina alterniflora, Poaceae) invading San Francisco Bay. American Journal of Botany 86: $131-139$.

Danzmann, R.G., M.M. Ferguson, F.W. Allendorf, and K.L. Knudsen. 1986. Heterozygosity and developmental rate in a strain of rainbow trout. Evolution 40:86-93.

DEBARR, G.L. 1957. The damage potential of a flower thrips in slash pine seed orchards. Journal of Forestry 67:326-327.

DEspain, D.W. 1987. History and results of prescribed burning of pinyon-juniper woodland on the Hualapai Indian Reservation in Arizona. Pages 145-151 in R.L. Everett, editor, Proceedings-pinyon-juniper conference. General Technical Report INT-215, USDA Forest Service, Intermountain Research Station, Ogden, UT.

Dickman, A. 1978. Reduced fire frequency changes species composition of a ponderosa pine stand. Journal of Forestry 76:24-25.

Dickmann, D.I., and T.T. Kozlowski. 1969. Seasonal growth patterns of ovulate strobili of Pinus resinosa in central Wisconsin. Canadian Journal of Botany 47: 839-848.

Diggle, P.J. 1975. Robust density estimation using distance methods. Biometrika 62:39-48.

EidT, D.C., AND H.G. MacGillivary. 1972. Resistance of seven fir species to spruce budworm and other insects. Bimonthly Research Notes 28:2-3.

Ellstrand, N.C., AND D.R. Elam. 1993. Population genetic consequences of small population size: implications for plant conservation. Annual Review of Ecological Systems 24:217-242.

Evans, R.A. 1988. Management of pinyon-juniper woodlands. General Technical Report INT-249, USDA Forest Service, Intermountain Research Station, Ogden, UT.

Everett, R.L., and W. Clary. 1985. Fire effects and revegetation on juniper-pinyon woodlands. Pages 33-37 in K. Sander and J. Durham, editors, Rangeland fire effects: a symposium, 1984 November 27-29. USDI Bureau of Land Management, Idaho State Office, Boise.

FAHRIG, L. 1997. Relative effects of habitat loss and fragmentation on population extinction. Journal of Wildlife Management 61:603-610.

Fauss, D.L., and W.R. Pierce. 1969. Stand conditions and spruce budworm damage in western Montana forests. Journal of Forestry 67:322-325.

Ferrell, G.T., W.J. Ostrosina, and C.J. Demars, Jr. 1933. Assessing the susceptibility of white fir to the fir engraver, Scolytus ventralis (Coleoptera: Scolytidae), using fungal inoculation. Canadian Entomologist 125:895-901.

Fisher, R.A. 1935. The logic of inductive inference. Journal of the Royal Statistical Society 98:39-54.

Gaines, M.S., J.E. Diffendorfer, R.H. Tamarin, and T.S. Whiтtam. 1997. The effect of habitat fragmentation on the genetic structure of small mammal populations. Journal of Heredity 88:294-304. 
Gambliel, H., and R. Croteau. 1984. Pinene cyclasses I and II. Journal of Biological Chemistry 259:740-748.

GARCIA, D. 1998. Interaction between juniper, Juniperus communis $\mathrm{L}$. and its fruit pest insects: pest abundance, fruit characteristics and seed viability. Acta Oecologica 19:517-525.

Garcia, D., R. Zamora, J.M. Gomez, P. Jordano, and J.A. HODAR. 2000. Geographical variation in seed production, predation, and abortion in Juniperus communis throughout its range in Europe. Journal of Ecology 88:436-446.

GodT, M.J.W., J.L. Hamrick, and S. Bratton. 1995. Genetic diversity in a threatened wetland species Helonias bullata (Liliaceae). Conservation Biology 9:596604.

Godt, M.J.W., B.R. Johnson, And J.L. Hamrick. 1997. Genetic diversity and population size in four rare southern Appalachian plant species. Conservation Biology 10:796-805.

GoYer, R.A., AND L.H. NACHOD. 1976. Loblolly pine cone and seed losses to insects and other factors in a Louisiana seed orchard. Forest Science 22:386-391.

HaLdane, J.B.S. 1954. An exact test for randomness of mating. Journal of Genetics 52:631-635.

Hamrick, J.L., AND M.J.W. GodT. 1990. Allozyme diversity in plant species. Pages 43-63 in A.H.D. Brown, M.T. Clegg, A.L. Kahler, and B.S. Weir, editors, Plant population genetics, breeding, and genetic resources. Sinauer Associates, Inc., Sunderland, MA.

1996. Conservation genetics of endemic plant species. Pages 281-304 in J.C. Avise and J.L. Hamrick, editors, Conservation genetics: case histories from nature. Chapman and Hall, New York.

Hamrick, J.L., A. Schnabel, and P.V. Wells. 1994. Distributions of genetic diversity within and among populations of Great Basin conifers. Pages 147-161 in K.T. Harper, L.L. St. Clair, K.H. Thorne, and W.M. Hess, editors, Natural history of the Colorado Plateau and Great Basin. University Press of Colorado, Niwot.

HaRD, J.S. 1963. Frost damage to red pine conelets. USDA Forest Service Research Note LS-5, U.S. Forest Experiment Station, St. Paul, MN.

Hardon, E. 1961. Developmental genetics and lethal factors [translation by V. Mittoch]. Methuen and Company, Ltd., London.

HartL, D.L., and A.G. Clark. 1997. Principles of population genetics. Sinauer Associates, Inc., Chicago, IL.

HerRera, J. 1991. Allocation of reproductive resources within and among inflorescences of Lavandua stoechas (Lamianceae). American Journal of Botany 78:789-794

Horner, J.W., R.G. Cates, and J. Gosz. 1987. Tannin, nitrogen, and cell wall composition of green vs. senescent Douglas fir foliage: within and between stand differences in stands of unequal density. Oecologia 72:515-519.

HuH, M.K., AND H.W. HuH. 2000. Genetic diversity and population structure of Juniperus rigida (Cupressaceae) and Juniperus coreana. Evolutionary Ecology 14:87-98.

Kennedy, J.S., AND C.O. Boоth. 1951. Host alteration in Aphis fabae, feeding preferences and reproductive success in relation to age and kind of leaves. Annals of Applied Biology 38:25-64.

Krugman, S.L. 1966. Freezing spring temperatures damage knobcone pine. USDA Forest Service Research
Paper PSW-37, U.S. Forest and Range Experimental Station, Berkeley, CA.

LALONDE, R.G., AND B.D. RoItBerg. 1989. Resource limitation and offspring size and number of trade-offs in Cirsium arvense (Asteraceae). American Journal of Botany 76:1107-1113.

1994. Mating system, life history, and reproduction in Canada thistle (Cirsium arvense; Asteraceae). American Journal of Botany 81:21-28.

LEDIG, FT. 1986. Heterozygosity, heterosis, and reproductive success in outbreeding plants. Pages 77-104 in M.E. Soule, editor, Conservation biology: the science of scarcity and diversity. Sinauer Associates, Inc., Sunderland, MA.

LEVIN, D.A. 1984. Inbreeding depression and proximitydependent crossing success in Phlox drummondii. Evolution 38:116-127.

1989. Inbreeding depression in partially self-fertilizing Phlox. Evolution 43:1417-1423.

Lewis, P.O., AND D. ZaYKIn. 2001. Genetic data analysis: computer program for the analysis of allelic data, version 1.0 (d16c) [online freeware]. Available from: http://lewis.eeb.uconn.edu/lewishome/software.html

Loenle, C. 1988. Tree life history strategies: the role of defenses. Canadian Journal of Forest Research 18: 209-222.

Loveless, M.D., AND J.L. Hamrick. 1984. Ecological determinants of genetic structure in plant populations. Annual Review of Ecology and Systematics 15:65-95.

LyFord M.E., S.T. Jackson, J.L. Betancourt, S.T. Gray. 2003. Influence of landscape structure and climate variability on late Holocene plant migration. Ecological Monographs 73:567-583.

Mantel, N. 1967. The detection of disease clustering and a generalized regression approach. Cancer Research 27:209-220.

MatTson, W.J. 1978. The role of insects in the dynamics of cone production of red pine. Oecologia 33:327-349.

McDonald, G. 1985. Heritability in resistance in Douglas-fir to western spruce budworm. Pages 96-107 in L. Safranyik, editor, The role of the host in the population dynamics of forest insects. Canadian Forestry Service and USDA Forest Service, Pacific Forest Research Centre, Victoria, British Columbia, Canada.

NaKamuRA, R.R. 1988. Seed abortion and seed size variation within fruits of Phaseolus vulgaris: pollen donor and resource limitation effects. American Journal of Botany 75:1003-1010.

NEI, M. 1972. Genetic distance between populations. American Naturalist 106:283-292.

1978. Estimation of average heterozygosity and genetic distance from a small number of individuals. Genetics 89:583-590.

Nickrent, D.L., AND D. Wiens. 1989. Genetic diversity in the rare California shrub Dedeckera eurekensis (Polygonaceae). Systematic Botany 14:245-253.

NowaK, C.L., R.S. NowaK, R.J. Tausch, and P.E. Wigand. 1994. Tree and shrub dynamics in northwestern Great Basin woodland and shrub steppe during the Late-Pleistocene and Holocene. American Journal of Botany 81:265-277.

OdRzykoski, I.J., AND L.D. GotTlieb. 1984. Duplication of genets coding 6-phosphogluconate dehydrogenase Clarkia (Onagraceae) and their phylogenetic implication. Systematic Botany 9:479-489.

Ortiz, P.L., M. ArRest, and S. TAlaVera. 1998. Low reproductive success in two subspecies of Juniperus 
oxycedrus L. International Journal of Plant Sciences 159:843-847.

Parker, K.C., J.L. Hamrick, and A.J. Parker. 1997. Allozyme diversity in Pinus virginiana (Pinaceae): intraspecific and interspecific comparisons. American Journal of Botany 84:1372-1382.

PolLARD, J.H. 1971. On distance estimators of density in randomly distributed forest. Biometrics 27:991-1002.

RohlF, F.J. 1992. NTSYS-PC. Numerical taxonomy and multivariate analysis system, version 1.70. Applied Biostatistics, Setauket, NY.

Schiller, G., M.T. Conckle, and L. Grunwald. 1985. Local differentiation among Mediterranean populations of Aleppo pine in their isozymes. Silvae Genetica 35:11-19.

Soltis, D.E., D.H. Haufler, D.C. Darrow, and J. GASTONY. 1983. Starch gel electrophoresis of ferns: a compilation of grinding buffers, gel and electrode buffers, and staining schedules. American Fern Journal 73:9-27.

Sorenson, F. 1969. Embryonic load in coastal Douglas-fir, Pseudotsuga menziesii var. menziesii. American Naturalist 103:389-398.

SoREnSON, F.C. 1999. Relationship between self-fertility, allocation of growth, and inbreeding depression in three coniferous species. Evolution 53:417-425.

SPRINGFIELD, H.W. 1976. Characteristics and management of southwestern pinyon-juniper ranges: the status of our knowledge. Research Paper RM-160 USDA Forest Service, Rocky Mountain Forest and Range Experiment Station, Fort Collins, CO.

SPSS. 1999. SYSTAT 9, Statistics for windows. SPSS, Chicago, IL.

Stephenson, A.G. 1980. Fruit set, herbivory, fruit reduction, and the fruiting strategy of Catalpa speciosa (Bignoniaceae). Ecology 61:57-64.

1981. Flower and fruit abortion: proximate causes and ultimate functions. Annual Review of Ecological Systems 12:253-279.

Stevens, R. 1999. Mechanical chaining and seeding. Pages 281-284 in S.B. Monson and R. Stevens, compilers, Ecology and management of pinyon-juniper communities within the Interior West. Proc. RMRS-P-9, USDA Forest Service, Rocky Mountain Research Station, Ogden, UT.

StURgEON, K. 1979. Monoterpene variation in ponderosa pine xylem resin related to western pine beetle predation. Evolution 33:803-814.

Sun, M. 1996. Effects of population size, mating system and evolutionary origin on genetic diversity in Spiranthes sinensis and S. hingkongensis. Conservation Biology 10:745-795.

TaUsCH, R.J. 1999. Historic pinyon and juniper woodland development. Pages 12-14 in S.B. Monson and R. Stevens, compilers, Ecology and management of pinyon-juniper communities within the Interior West. Proc. RMRS-P-9, USDA Forest Service, Rocky Mountain Research Station, Ogden, UT.

Terry, R.G., R.S. Nowak, and R.J. Tausch. 2000a. Genetic variation in chloroplast and nuclear ribosomal DNA in Utah juniper (Juniperus osteosperma, Cupressaceae): evidence for interspecific gene flow. American Journal of Botany 87:250-258.
Terry, R.G., R.J. Tausch, and R.S. Nowak. 2000b. Hybridization and genetic diversity in populations of Utah (Juniperus osteosperma) and western (Juniperus occidentalis) juniper: evidence from resource sciences. University of Nevada Press, Reno.

Van der Merwe, M., M.O. Winfield, G.M. Arnold, and J.S. PARKer. 2000. Spatial and temporal aspects of the genetic structure of Juniperus communis populations. Molecular Ecology 9:379-386.

Wagner, M., K. Clancy, and R. Tinus. 1989. Maturational variation in needle essential oils from Pseudotsuga menziesii, Abies concolor, and Picea engelmannii. Phytochemistry 28:765-770.

WASER, N.M. 1993. Sex, mating systems, inbreeding, and outbreeding. In N.W. Thornhill, editor, The natural history of inbreeding and outbreeding. University of Chicago Press, Chicago, IL

WeIr, B.S. 1996. Genetic data analysis II. Sinauer Associates, Inc., Sunderland, MA

White, T.C.R. 1974. A hypothesis to explain outbreaks of looper caterpillars with special reference to populations of Selidosema suavis in a plantation of Pinus radiata in New Zealand. Oecologia 16:279-301.

Whitlock, M.C., AND D.E. McCauley. 1999. Indirect measures of gene flow and migration. Heredity 82:117-125.

WIENS, D. 1984. Ovule survivorship, brood size, life history, breeding systems, and reproductive success in plants. Oecologia 64:47-53.

Wiens, D., L. Allphin, D.H. Mansfield, and G. ThackRAY. 2002. Developmental failure and loss of reproductive capacity as a factor in extinction: a nine-year study of Dedeckera eurekensis (Polygonaceae). Aliso 21:55-63.

Wiens, D., C.L. Calvin, C.A. Wilson, C.I. Davern, D. Frank, and S.R. SEavey. 1987. Reproductive success, spontaneous embryo abortion and genetic load in flowering plants. Oecologia 71:501-509.

WILCOX, B.A. 1980. Insular ecology and conservation. Pages 95-117 in M.E. Soulé and B.A. Wilcox, editors, Conservation biology: an evolutionary-ecological perspective. Sinauer Associates, Inc., Sunderland, MA.

Wright, S. 1921. Systems of mating. Genetics 6:111-178. 1943. Isolation by distance. Genetics $28: 114-138$. 1946. Isolation by distance under diverse systems of mating. Genetics 31:39-59.

1951. The genetical structure of populations. Annals of Eugenics 15:323-354.

ZAR, J.H. 1996. Biostatistical analysis. 3rd edition. Prentice-Hall, London.

ZARN, M. 1977. Ecological characteristics of pinyonjuniper woodlands on the Colorado Plateau: a literature survey. Technical Note T/N 310, USDI Bureau of Land Management, Denver Service Center, Denver, $\mathrm{CO}$.

Zhang, J.W., N.B. Klopfenstein, G.W. Peterson. 1997. Genetic variation in disease resistance of Juniperus virginiana and $J$. scopulorum grown in eastern Nebraska. Silvae Genetica 46:11-16.

Received 21 April 2005 Accepted 12 January 2007 